Acta Veterinaria (Beograd), Vol. 63, No. 5-6, 549-568, 2013.

DOI: 10.2298/AVB1306549J

UDK: $636.12+796.012 .6: 577.125 .2+577.152 .1 / .2$

\title{
INFLUENCE OF PHYSICAL ACTIVITY OF RACEHORSES ON LACTATE DEHYDROGENASE AND CREATINE KINASE ACTIVITIES, AND PROTEIN SYNTHESIS
}

JOVIĆ S, STEVANOVIĆ JELKA, BOROZAN SUNČICA, DIMITRIJEVIĆ B and MILOSAVLJEVIĆ P

University of Belgrade, Faculty of Veterinary Medicine, Serbia

(Received $21^{\text {st }}$ January 2013)

The aim of the research was to assess the effects of physical activity of various intensity on the degree of damage to certain organs resulting from increased free radical production, as well as the adaptability of the organism to physical exercise.

Two groups of healthy 3-5-year-old full-blooded racehorses were assessed. The first one ran a 2400-meter gallop race, which is considered a short-lasting, intense physical activity; lipid status was assessed prior to, and 48 and $72 h$ after the race. The second group ran a forty-kilometer endurance ride, which is a long-lasting moderate physical activity; the lipid status was assessed immediately before, on finishing and 48, 72, 96, 120 and $144 \mathrm{~h}$ after the race.

The total activity of $L D H$ changed $72 h$ and $96 h$ following the gallop race $(p>0.05)$, whilst the maximum activity was measured immediately after the endurance ride. By means of electrophoresis $L D H$ in all the horses 5 isoforms were detected. The activity of LDH1 $72 \mathrm{~h}$ after the gallop race significantly rose in comparison to the one before the race $(p<0.05)$, whilst the activity of all other isoenzymes, LDH2-LDH5, did not change significantly ( $p>0.05)$. Following the endurance ride $\mathrm{LDH} 1$ activity rose at all sampling times, reaching the maximum at $96 h$ and $144 h$ in comparison to the values both before and on finishing the ride $(p<0.01)$. The increase in the activity of LDH2 was significantly higher $48 h, 72 h, 96 h$ and $120 h(p<0.05)$ after the race in comparison to that before the race, and at $48 \mathrm{~h}$, $72 h, 96 h, 120 h$ and $144 h(p<0.05)$ in comparison to the values on finishing the race. $\mathrm{LDH} 3$ activity significantly decreased and $\mathrm{LDH} 5$ rose immediately after the endurance ride $(p<0.01)$, whilst $\mathrm{LDH} 4$ significantly rose at all times following the endurance ride $(p<0.01)$. The CK activity pointed to high, medium and low degree of adaptation of horses to physical activity. 
The concentrations of total proteins, albumins and globulins remained within the physiological range at all sampling times, with the exception of $96 h$ after the endurance ride, when the fall in albumin concentration was significant $(p<0.01)$.

Long-lasting physical activity of low intensity leads to cellular damage in the myocardium, muscles, liver and to hypoalbuminaemia, which is a consequence of free radical production.

Key words: creatine kinase, endurance ride, gallop race, horses, lactate dehydrogenase, proteins

\section{INTRODUCTION}

Numerous studies confirmed that reactive oxygen species (ROS) may contribute to altered homeostasis due to increased physical activity, i.e. muscle fatigue and damage (Pyne, 1994; Powers and Lennon, 1999; Marlin et al., 2002; Cheung et al., 2003; Close et al., 2005). Oxydative stress may occur as a result of physical activity itself, or myopathies due to exercise and intense haemolysis resulting from increased lipid peroxidation. In aerobic endurance stress there is an increase in the production of ROS. Mitochondria in active muscles are presumably the main source of ROS, although free radicals are produced by erythrocytes, as well as in the inflammatory response which accompanies the increased muscular activity.

ROS may be synthesised during or after physical activity in active muscles and in ischemic tissues. In vivo they are produced in various tissues, in particular in skeletal muscles especially during physical activity. All ROS-producing cells, especially those in skeletal muscles, are involved in intense activity during and after long-lasting muscle contractions (Close et al., 2005). The main culprit for the rise in production in these conditions is the increased respiration rate, since the need for oxygen is then enormously increased. Thus, the use of oxygen in muscles in stenuous exercise may be even 100-200 times as active as at rest (Davies et al., 1982; Sjodin, 1990; Chevion et al., 2003).

It is certain that oxidative stress induced by exercise contributes to accelerated development of muscle fatigue and damage (Hargreaves et al., 2002; Marlin et al., 2002; Williams et al., 2004; Gondim et al., 2009) leading to intolerance towards exercise and diminished its performance in various animal species, as well as to a decline in the body's defense capacity.

Myoglobin released from damaged skeletal muscle cells and haemoglobin from erythrocytes, which undergo intense haemolysis during significant blood pressure increase or due to peroxidation of membrane lipids in physical activity, both may increase lipid peroxidation. Lipid peroxidation inevitably leads to reactive aldehydes, which may be transported from the place of initial damage to other tissues. It is found that ROS may cause damage to skeletal muscles not only at 
the places where produced (Close i sar., 2005). Oxidative damage resulting from exercise is especially severe in skeletal muscles and leads to poor work capacity (Reid et al., 1992; Pyne, 1994; Ramzan and Palmer, 2010). Plasma contains proteins, such as haptoglobin haemopexin, which bind free haemoglobin, haeme iron, and thus neutralize the possible induction of lipid peroxidation.

Abeni et al. (2013) detected increased creatine kinase (CK) activity in 1015 -year old horses compared with other ages. To assess apoptosis resulting from training, Boffi et al. (2002) performed three-month-long research on fullblooded horses on a threadmil. In samples obtained by muscle biopsy they found increased activity of CK in comparison to untrained horses. DNA fragmentation was also proven, which both indicate the existence of a training-induced apoptosis in skeletal muscle cells. Apoptosis or programmed cell death is a genetically controlled response in terms of suicide provoked by DNA fragmentation. Common drivers of apoptosis are $\mathrm{Ca}^{2+}$ and ROS, which are present in the pathogenesis of exercise-induced myopathy. It is very likely that this activated apoptosis, in which the injured muscle cells trigger their own death and are replaced by new stronger ones, is to start the damage-repair cycle, which is actually the mechanism of training-induced increase in muscle mass.

Physical activity leads to increased production of ROS in athletes, to the point that may exceed antioxidant defenses and lead to oxidative stress. Oxidative stress resulting from physical exercise does not lead to changes in liver function, but increases the level of thiobarbituric reactive species (TBARS) in skeletal muscle and red blood cells (Soares et al., 2011) which may lead to increased levels of lactate dehydrogenase (LDH), whose activity increases in the presence of hydroxyl radicals that cause muscle damage (Watson et al., 2005). Two-tosix-year-old horses have a higher activity of LDH than older ones according to Kirschvink et al. (2006). However, Abeni et al. (2013) found the lowest activity in those between 10 and 15 years of age. Continuous high-intensity training increases the activity of LDH in racehorses and influences the activity of enzymes involved in the metabolism of glucose and lipids (Arai et al., 2002, 2003; Li et al., 2012).

Strenuous exercise leads to certain increase in the intensity of metabolism and therefore increases the production of ROS and threatens the antioxidant defense system. Research on the effects of oxidative stress during strenuous exercise, performed by Chevion et al. (2003) was performed on 31 males loaded with $35 \mathrm{~kg}$ of extra weight, who walked extreme marches of 50 and $80 \mathrm{~km}$ at sea level. The $50 \mathrm{~km}$-long march was completed by 29 participants but only 16 completed the $80 \mathrm{~km}$ march. Both marches led to an increase in plasma levels of uric acid by $25 \%$ and $37 \%$, respectively, which was a result of intensified metabolic rate including the metabolism of purine nucleotides. In addition, approximately a 10 -fold increase in creatine phosphokinase activity was detected in the plasma. Plasma protein carbonyl content, markers of protein oxidative damage, decreased significantly during both marches. These results are discussed taking into account 
that the increase in breathing rate during physical activity leads to a production of ROS over the one which can be removed by the antioxidant system.

LDH plays an important role in glycolysis catalysing its last stage. Since it is in the cytoplasm, when cell damage occurs, LDH easily escapes into the extracellular space, resulting in its increased plasma activity. Measurement of total serum LDH has little diagnostic value because its location in the cells of different tissues. Given the distribution of LDH isoenzymes in various organs, it is important to specify them.

The increased activities of CK and LDH in serum immediately after exercise is due to a selective increase in the permeability of muscle membranes as a result of increased peroxidation which occurred during exhausting exercise. The degree of peroxidation was determined by the increase in TBARS (Anderson, 1975; Soares et al., 2011). In the research conducted by Morillas-Ruiz et al. (2006), an increase of CK and TBARS was detected after exercise, which was confirmed by the results obtained in horses. However, it is also possible that in exhausting exercise there is an adaptation of muscles followed by changes in the CK activity (Piccione et al., 2009; Lawan et al., 2010; Soares et al., 2011). High CK levels may correlate with the status of physical training, whilst persistently high levels indicate subclinical myopathy (Piccione et al., 2009).

Besides protein whose concentration increases significantly during the acute phase, there are so-called "negative acute phase proteins," which decrease in the acute phase of infection and stress. Such proteins include albumins, whose concentrations decrease by 10-50\% (Toussaint, 2005; Abeni et al., 2013). The reason for these changes in protein concentrations in the acute phase of infection is their reduced production or increased degradation. In the case of albumins, there may not be a real decline in concentration, but it often seems so as a reflection of increased synthesis of other acute-phase proteins, which are all plasma globulins, and thus alter the albumin-globulin ratio.

The decrease in albumins and transferrin in humans after finishing exercise and a 1,600-km ultramarathon was proven by Fallon and Sivyer (1999) and Fallon (2001).

ROS are able to attack all the major classes of biological macromolecules, proteins, DNA (Sen, 1995; Tauler et al., 2004; Aguilo et al., 2005; Tauler et al., 2006) and especially lipids (McBride and Kraemer, 1999; Close et al., 2005). Increased oxygen consumption, accompanied by a sharp rise in production of oxygen derivatives, is responsible for lipid peroxidation of cell membranes. It leads to a degradation of proteins and enzymes and the consequent development of oedema in tissues. Saturated fatty acids and those with one double bond are much more resistant to ROS than polyunsaturated fatty acids (PUFAs), which are abundant in cell membranes and thus easily attacked by ROS (Close et al., 2005), which is inevitably accompanied by impairment of cell functions.

ROS generated during increased muscle activity are potent inducers of oxidative damage to various cellular molecules by means of protein oxidation 
(Chevion et al., 2003). Oxidative damage to cellular proteins involves modification of amino acids, changes in their secondary (due to the interaction of radicals with the skeleton of the polypeptide chain) and tertiary structures, indirect damage by the activation of proteolytic enzymes with hypochloric acid and products of lipid peroxidation. All these changes result in an alteration in membrane permeability due to altered activity of enzyme molecules in the cell membrane, aggregation and inactivation of receptor proteins or dysfunction of transport proteins and, consequently, lead to disrupted cell signaling, ionic transport and homeostasis. The circuit of damage does not complete here but continues, so that nonspecific permeability to ions, especially $\mathrm{Ca}^{2+}$, further destablise biomembranes, by activation of calcium-dependent proteases, including phospholipase A2. Its release initiates a cascade of reactions which lead to the production of by-products in peroxidation processes, lipid mediators and neuropeptides, which exacerbated the inflammatory response (Slater, 1987; Halliwell and Gutteridge, 1990).

Enzyme components of the primary antioxidant defense are comprised of antioxidant molecules which collect free radicals, such as the family peroxiredoxin proteins (function as collectors of superoxide and hydrogen peroxide). All these molecules block the initiation of the chain reaction of ROS and associated lipid peroxidation (Margaritis et al., 2003). Each one detoxifies some of the ROS, and protein antioxidants are supplemented with nonprotein ones (intracellular ascorbate, glutathione etc.). It is very important that vitamin $E$ reacts with peroxyl radicals faster than they may react with unsaturated fatty acids and proteins. Vitamin E in blood plasma protects lipoproteins from oxidation (Halliwell, 1991), and is a major antioxidant of LDL molecules.

Sources of ROS during exercise are enhanced purine oxidation, damage to iron-containing proteins, disruption of homeostasis of $\mathrm{Ca}^{2+}$ and $\mathrm{ROS}$ production induced in endothelial cells. In addition, activated neutrophils, which infiltrate the muscles after damage caused by exercise, can also produce increased ROS (Chevion et al., 2003; Close et al., 2005).

\section{MATERIAL AND METHODS}

\section{Animals and blood sampling}

The research was performed on two groups of 3-5-year old, male, full-blooded racehorses in the Republic of Serbia. The first one comprised 12 clinically healthy animals which ran a 2400-meter-long gallop race and were kept in stables at the Belgrade racecourse. The second group comprised 13 racehorses which ran the 40-kilometer-long endurance ride. These were kept in stables at the Belgrade or Pančevo racecourse.

All blood samples were taken from the jugular vein without adding any anticoagulant, from gallopers before, and 48 and $72 \mathrm{~h}$ after the race, and from those who ran the endurance ride immediately before and after the activity, as well as $48,72,96,120$ and $144 \mathrm{~h}$ after the completion of the ride. 
Serum was separated from blood which coagulated spontaneously at room temperature, centrifuged at $3000 \mathrm{rpm}$ for 10 minutes, frozen and kept at $-20^{\circ} \mathrm{C}$ until analyzed.

\section{Biochemical analysis}

Relative isoenzyme distribution of lactate dehydrogenase

LDH isoenzymes (LDH1, LDH2, LDH3, LDH4 and LDH5) were detected by vertical electrophoresis, on denaturing 7.5\% PAG gel, using TRIS - glicine buffer, according to the method of Laemmli (HOEFFER MINI VE, Amersham, LKB, 2117, Bromma, Uppsala Sweden). The detection of bands was performed with sodium lactate (substrate) in the presence of NADH and tetrazolium blue. The colour intensity of the formazan is measured by densitometry using Scion Image Beta 4.02 software for Windows. The activity of each isoenzyme is expressed as a percentage of total LDH activity.

\section{Creatine kinase activity}

The serum activity of creatine kinase was detected by an enzymatic method, with an assay kit (Bioanalytica, BioSystem).

\section{Total protein concentration}

The concentration of total proteins in the serum was determined by a spectrophotometric, biuret method - Kerr's modification of the method described by Gornall. Absorbances were read on a spectrophotometer CECIL CE 2021 UVI VIS, $540 \mathrm{~nm}$. Protein concentrations were calculated from the standard curve $(y=0.0022 x+0.0121)$, adjusted to solutions of bovine serum albumins (BSA) in concentrations from $10 \mathrm{~g} / \mathrm{L}$ to $100 \mathrm{~g} / \mathrm{L}$.

\section{Albumine concentrations}

The concentrations of serum albumins were determined by spectrophotometric analysis, using the method with bromocresol green (BCG). The results were read on a spectrophotometer CECIL CE 2021 UV/VIS, measuring the adsorbance at $637 \mathrm{~nm}$, using BSA as a standard. Albumin concentrations were calculated from the standard curve $(y=0.0022 x+0.0121)$, adjusted to solutions of BSA in concentrations ranging from $10 \mathrm{~g} / \mathrm{L}$ to $100 \mathrm{~g} / \mathrm{L}$.

\section{Statistical analysis}

Statistical analysis of the results was performed with GraphPad Prism 5. Statistic significance was determined using ANOVA (Tukey's test and Dunnett's test) and t-test. The minimum level of statistical significance was set at $p<0.05$. 
The correlation between the parameters tested was examined according to Person's correlation coefficient ( $r$ ), the regression line (Fy) and testing the significance of correlation and regression coefficients.

\section{RESULTS}

Activity of lactate dehydrogenase and its isoenzyme forms

(LDH1, LDH2, LDH3, LDH4 and LDH5)

The results of the determination of total LDH activity in the serum of horses which ran the gallop race and endurance ride are given in Table 1.

Table 1. Activity of total plasma LDH in horses which ran 2400-meter gallop race and 40-kilometer endurance ride (TA - total area).

\begin{tabular}{|c|c|c|c|}
\hline Sampling time & $\bar{X} \pm$ SD (TA) & min & max \\
\hline \multicolumn{4}{|c|}{ Gallop race } \\
\hline before race & $3136 \pm 771.8$ & 2051 & 4479 \\
\hline $72 \mathrm{~h}$ after the race & $3078 \pm 707.8$ & 2049 & 4432 \\
\hline 96 $\mathrm{h}$ after the race & $3256 \pm 800.8$ & 2379 & 4937 \\
\hline \multicolumn{4}{|c|}{ Endurance ride } \\
\hline before ride & $2530 \pm 672.4$ & 1528 & 3450 \\
\hline immediately after the ride & $4208 \pm 1421^{* *}$ & 2539 & 7642 \\
\hline 48 $\mathrm{h}$ after the ride & $2941 \pm 1132^{\#}$ & 1652 & 4833 \\
\hline $72 \mathrm{~h}$ after the ride & $2349 \pm 847.1^{\#}$ & 1104 & 3794 \\
\hline 96 $\mathrm{h}$ after the ride & $2151 \pm 801.1^{\# \#}$ & 1365 & 4235 \\
\hline $120 \mathrm{~h}$ after the ride & $3012 \pm 1137$ & 1136 & 4992 \\
\hline $144 \mathrm{~h}$ after the ride & $2718 \pm 998^{\# \#}$ & 1480 & 4367 \\
\hline
\end{tabular}

Data: means \pm SD

${ }^{*} p<0.05,{ }^{* *} p<0.01,{ }^{* * *} p<0.001$ The levels of statistical significance before and after the ride $\# p<0.05, \# p<0.01$. $p<0.001$ The levels of statistical significance immediately after the ride and $48 \mathrm{~h}$ to144h after the ride

The results showed that total LDH activity changed $72 \mathrm{~h}$ and $96 \mathrm{~h}$ after the gallop race $(p>0.05)$ and correlated positively with the concentrations of total proteins before $(r=0.7037, p<0.05)$, as well as $72 \mathrm{~h}(r=0.6096, p<0.05)$ and $96 \mathrm{~h}(r=0.8205, p<0.01)$ after the race. The analysis of activity following the endurance ride revealed highest values on finishing the ride, which was significant in comparison to those before $(p<0.01)$, and $48 \mathrm{~h}(\mathrm{p}<0.05), 72 \mathrm{~h}(\mathrm{p}<0.001), 96 \mathrm{~h}$ $(p<0.001)$ and $144 \mathrm{~h}(\mathrm{p}<0.01)$ after the ride.

In all the horses in the experiment five isoenzime forms of LDH were detected by means of electrophoresis (Figure 1). 

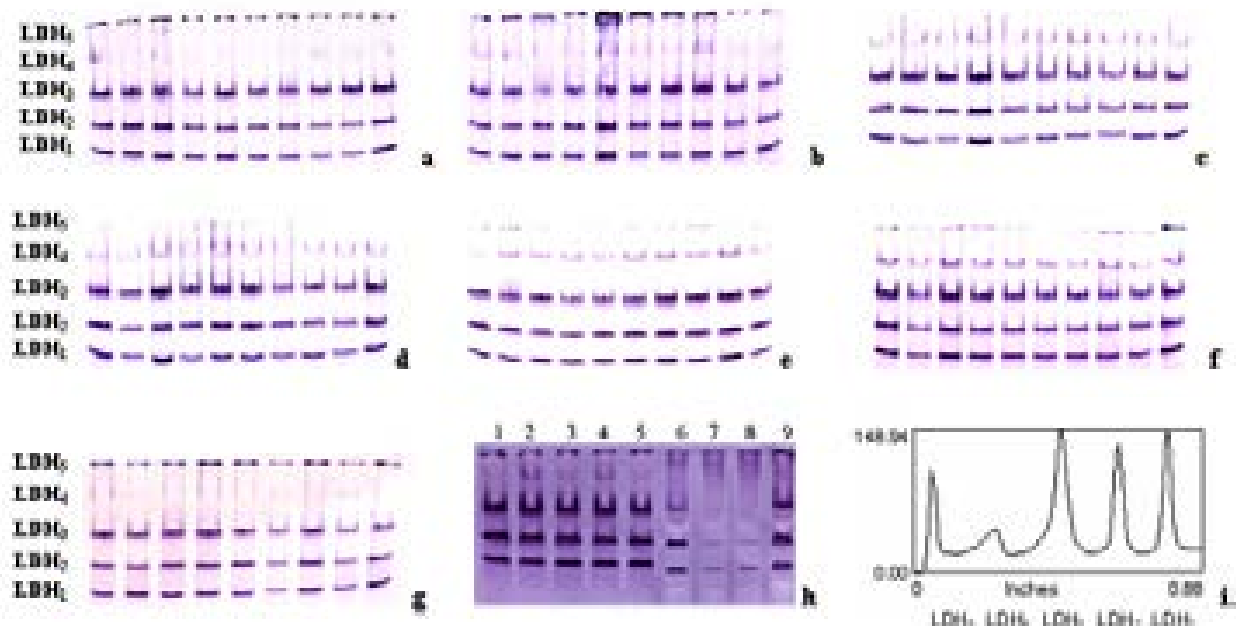

Figure 1. Electrophoresgrams of isoenzymatic distribution of total LDH (LDH5, LDH4, LDH3, LDH2 and LDH1) in horse plasma on 7.5\% PAGE-gel in non-denaturing conditions before endurance ride (a), immediately after (b), $48 \mathrm{~h} \mathrm{(c),72} \mathrm{h} \mathrm{(d),} 96 \mathrm{~h}$ $(\mathrm{e}), 120 \mathrm{~h}(\mathrm{f})$ and $144 \mathrm{~h}$ after the ride $(\mathrm{g})$, before gallop race $1,4,7 ; 72 \mathrm{~h}$ after the race 2,5,8; and $96 \mathrm{~h}$ after the race 3,6,9 (h) and densitogram LDH1-5 (i)

The data derived from the assessment of the activity of isoenzyme forms LDH1 LDH2, LDH3, LDH4 and LDH5 in the plasma of horses which ran the gallop race and the endurance ride are presented in Table 2 and Figure 1.

The analysis of relative isoenzyme distribution of LDH proved a significant increase in the activity of LDH1 $72 \mathrm{~h}$ after the gallop race in comparison to the one before the race $(p<0.05)$, with a tendency to rise $96 \mathrm{~h}$ after finishing the ride $(p>0.05)$. The activity of other isoenzymes, LDH2 - LDH5, varied $72 \mathrm{~h}$ and $96 \mathrm{~h}$ after the race in comparison to the one which preceeded, but without a statistically significant difference $(p>0.05)$.

After the endurance ride the LDH1 activity had a tendency to grow at all sampling times compared to the period before and on finishing the ride. This isoenzyme exhibited maximum activity $96 \mathrm{~h}$ and $144 \mathrm{~h}$ after the ride, significantly higher than before and immediately after it $(p<0.01)$. The activity of LDH2 showed a similar pattern after the endurance ride as did LDH1: in all tested intervals the activity increased in comparison to the period before and immediately after the race, and was significantly higher $48 \mathrm{~h}(p<0.01), 72 \mathrm{~h}(\mathrm{p}<0.001), 96 \mathrm{~h}(\mathrm{p}<0.01)$ and $120 \mathrm{~h}(\mathrm{p}<0.05)$ after the ride than prior to it and $48 \mathrm{~h}, 72 \mathrm{~h}, 96 \mathrm{~h}, 120 \mathrm{~h}$ $(p<0.001)$ and $144 \mathrm{~h}$ after the ride $(p<0.05)$ than on completing the ride.

However, the activity of isoenzyme LDH3, which points to possible damage to the lungs, a significant decrease was proven on finishing the ride $(p<0.01)$ in comparison to the preceding value, whilst later there was no significant 


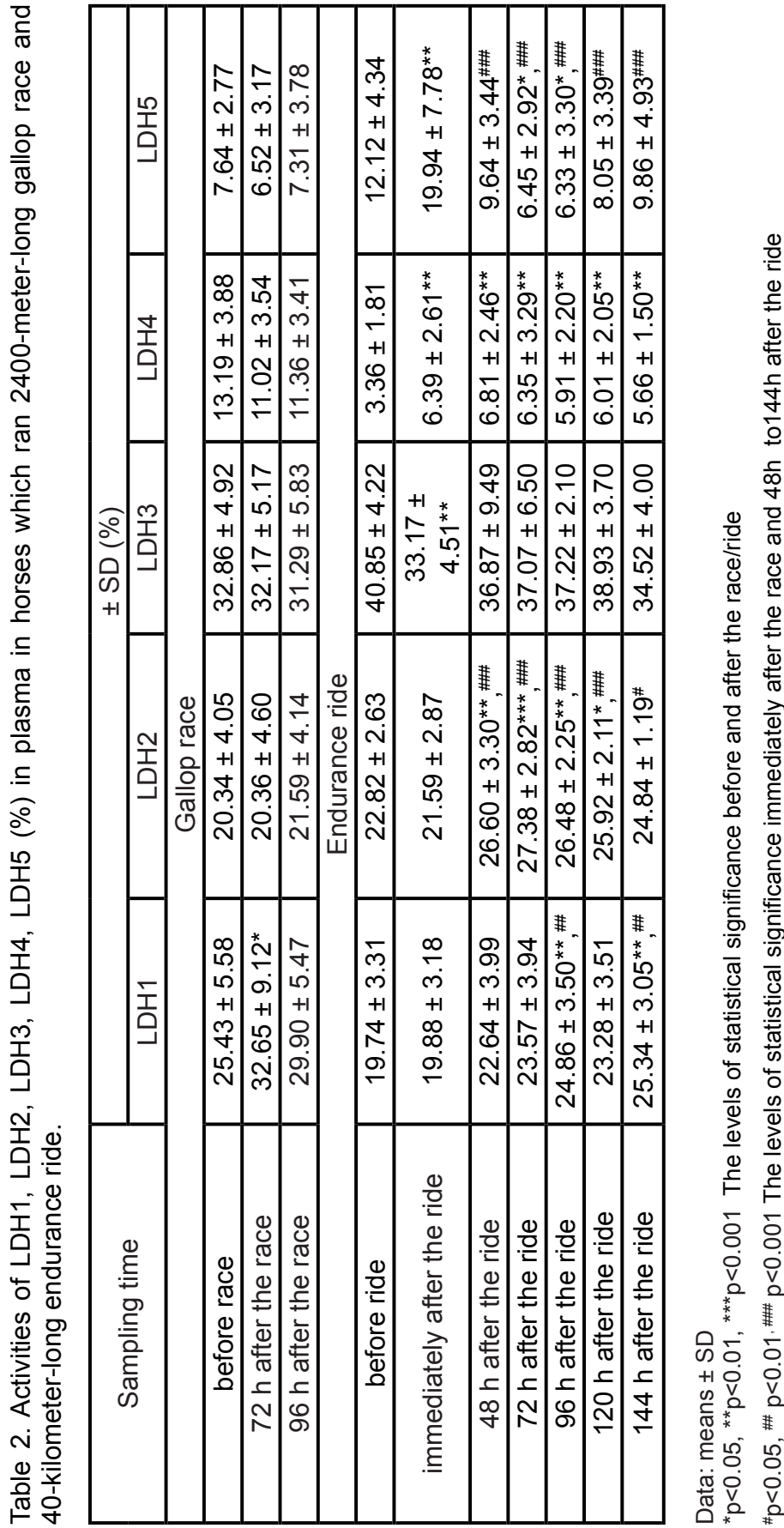


difference ( $p>0.05)$. By contrast, LDH4, which indicates the degree of muscular damage, significantly increased at all sampling times following the endurance ride $(p<0.01)$. Similarly, LDH5, which points to liver tissue damage, showed a statistically significant increase of activity, but only immediately on completing the ride $(p<0.01)$, compared to its activity before the ride, as well as after $48 \mathrm{~h}$ to $144 \mathrm{~h}$ after the ride (Table 2). In comparison to the value before the ride, the activity of LDH5 was roughly similar as soon as $48 \mathrm{~h}$ after the ride and remained so until the end of the trial. In addition, there was a significant decrease of LDH5 activity $72 \mathrm{~h}$, $96 \mathrm{~h}$ after the ride in comparison to the value which preceded the activity $(p<0.05)$.

Comparison the activity of lactate dehydrogenase and its isoenzyme forms (LDH1-LDH5) in horses which took part in gallop race and endurance ride

The comparison of total LDH activity in horses engaged in physical activity of various degree at the same sampling times (Figure 2), it is clear that the gallop ride led to more severe cell membrane damage and release of this enzyme into the extracellular space. This is confirmed by the statistical significance at $72 \mathrm{~h}$ $(p<0.05)$ and $96 \mathrm{~h}(\mathrm{p}<0.01)$ after the race/ride.

The kinetics of increased LDH1 activity differed between the two groups of horses, depending on the intensity of the physical activity. After gallop, the 72 -h-post-race increase was $28.39 \%$ and in the next $24 \mathrm{~h}$ was $17.58 \%$, while the endurance accounted for $19.40 \%$ and $25.93 \%$ increase in comparison to the basic level. Thus, the gallop race resulted in a higher degree of damage to cell membranes and LDH1 release into the extracellular space, which was demonstrated by high statistical significance of the difference in the LDH1 activity between the two groups of horses $72 h(p<0.01)$ and $96 h(p<0.05)$ following the race. Comparison of the LDH2 activity at the same time intervals after both races revealed a substantial increase in horses participating in the endurance ride in comparison to those which galloped, both $72 \mathrm{~h}(\mathrm{p}<0.001)$ and $96 \mathrm{~h}(\mathrm{p}<0.01)$ after the race. Similarly, the activitiy of LDH3 was significantly higher in horses completing the endurance ride than galloping race both $72 \mathrm{~h}(\mathrm{p}<0.05)$ and $96 \mathrm{~h}$ $(p<0.01)$ after the run. By contrast, the LDH4 activity at the same time intervals was significantly higher in galloping horses that those which participated in the endurance ride both $72 h(p<0.01)$ and $96 h(p<0.001)$ after crossing the finishing line. However, the activity of LDH5 remained roughly unchanged $(p>0.05)$.

\section{Creatine kinase activity}

The results of the analysis of creatine kinase activity in horses following the gallop race and endurance ride are presented in Table 3 and Figure 3.

The activity of creatine kinase increased significantly $72 \mathrm{~h}(p<0.001)$ and $96 \mathrm{~h}(\mathrm{p}<0.01)$ after the gallop race.

Following the endurance ride in horses highly adapted to physical activity creatine kinase did not vary significantly, whilst in those moderately adapted there was a significant difference on finishing the ride in comparison to the values both 

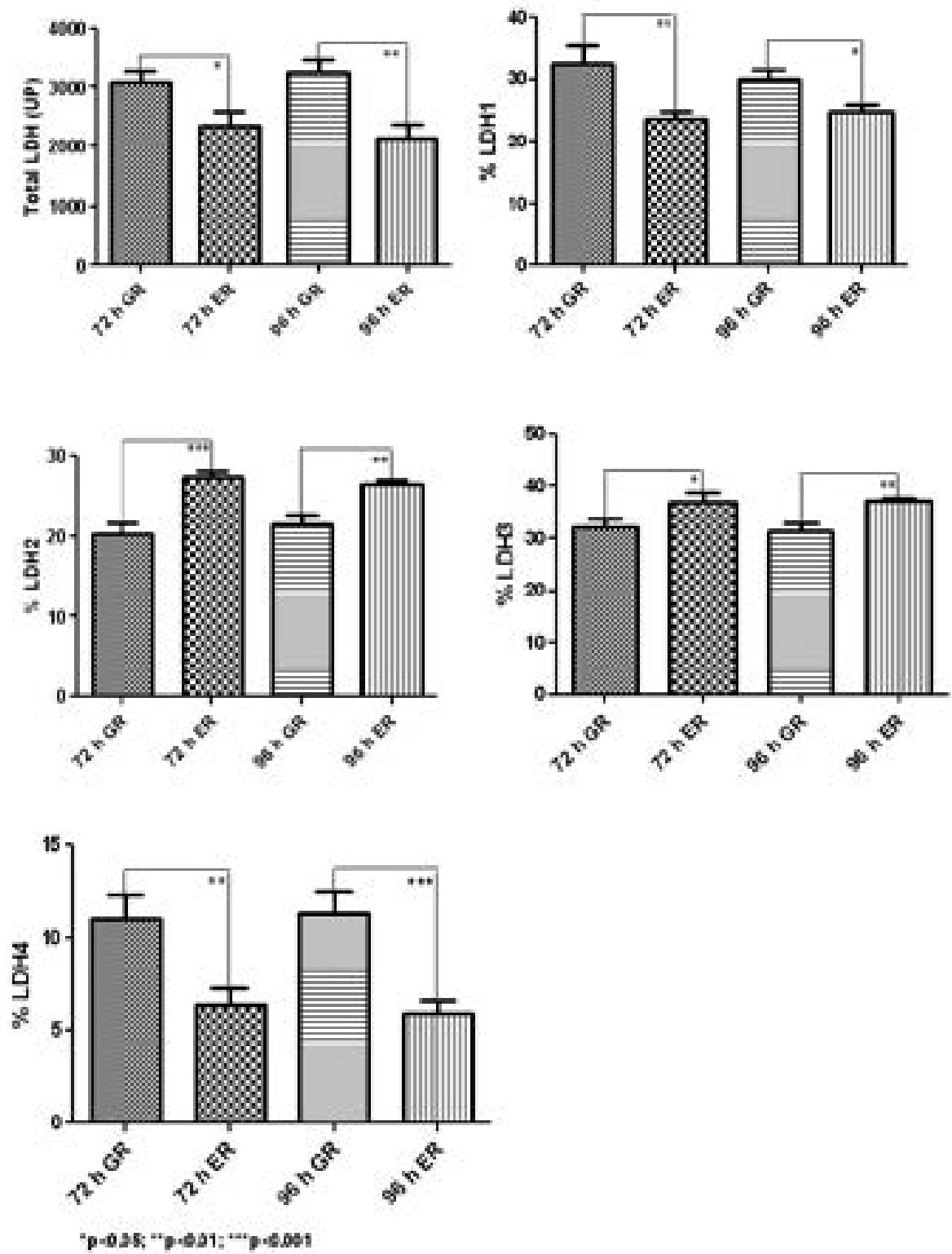

Figure 2. Activity of total LDH (UP), LDH1, LDH2, LDH3, LDH4 (\%) in plasma of horses which ran a 2400-metre long gallop race (GR) and those which ran 40-kilometrelong endurance ride (ER) at same time intervals - $72 \mathrm{~h}$ and $96 \mathrm{~h}$ after the end of the race/ride. 
before $(p<0.01)$ and $48 \mathrm{~h}-144 \mathrm{~h}$ after the ride $(\mathrm{p}<0.001)$. In horses with lowdegree of adaptation to physical activity maximum enzyme activity was noticed on completing the ride ( $p<0.001$ in comparison to all sampling times).

Table 3. Activity of creatine kinase (U/L) in serum of horses which ran 2400-meter-long gallop race and 40-kilometer-long endurance ride

\begin{tabular}{|c|c|c|c|}
\hline Sampling time & $\bar{X} \pm \mathrm{SD}(\mathrm{U} / \mathrm{L})$ & $\min$ & $\max$ \\
\hline \multicolumn{4}{|c|}{ Gallop race } \\
\hline before race & $62.30 \pm 16.10$ & 46.30 & 78.00 \\
\hline 72 h after the race & $165.00 \pm 37.28^{* * *}$ & 121.00 & 211.00 \\
\hline 96 h after the race & $124.60 \pm 26.20^{* *++}$ & 98.00 & 150.01 \\
\hline
\end{tabular}

\begin{tabular}{|c|c|c|c|}
\hline \multicolumn{4}{|c|}{ Endurance ride } \\
\hline \multirow{2}{*}{ Sampling time } & \multicolumn{3}{|c|}{$\bar{X} \pm \mathrm{SD}(\mathrm{U} / \mathrm{L})$} \\
\hline & Highly adapted & Moderetaly adapted & Slightly adapted \\
\hline before ride & $22.00 \pm 4.69$ & $100.5 \pm 42.02$ & $44.60 \pm 17.64$ \\
\hline immediately after the ride & $68.00 \pm 10.07$ & $169.0 \pm 14.07^{* *}$ & $500.4 \pm 76.45^{* * *}$ \\
\hline $48 \mathrm{~h}$ after the ride & $60.50 \pm 35.45$ & $52.00 \pm 22.38^{\# \# \#}$ & $75.80 \pm 30.34^{\# \#}$ \\
\hline $72 \mathrm{~h}$ after the ride & $50.00 \pm 7.62$ & $49.00 \pm 16.25^{\# \#}$ & $56.00 \pm 21.85^{\# \# \#}$ \\
\hline $96 \mathrm{~h}$ after the ride & $46.25 \pm 19.47$ & $70.50 \pm 29.24^{\# \#}$ & 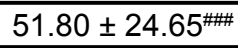 \\
\hline $120 \mathrm{~h}$ after the ride & $62.50 \pm 29.10$ & $59.50 \pm 13.77^{\# \#}$ & $63.40 \pm 22.21^{\# \# \#}$ \\
\hline $144 \mathrm{~h}$ after the ride & $66.25 \pm 32.62$ & $57.00 \pm 18.17^{\# \# \#}$ & $54.80 \pm 18.32^{\# \#}$ \\
\hline
\end{tabular}

Data: means \pm SD

${ }^{* *} p<0.01,{ }^{* *} p<0.001$ The levels of statistical significance before and after the race/ride

\# $p<0.05, \ldots+m p<001$ The levels of statistical significance immediately after the ride and $48 \mathrm{~h}$ to $144 \mathrm{~h}$ after the ride

${ }^{+} p<0.05$ statistically significant difference between $72 h$ to $96 \mathrm{~h}$ after the race
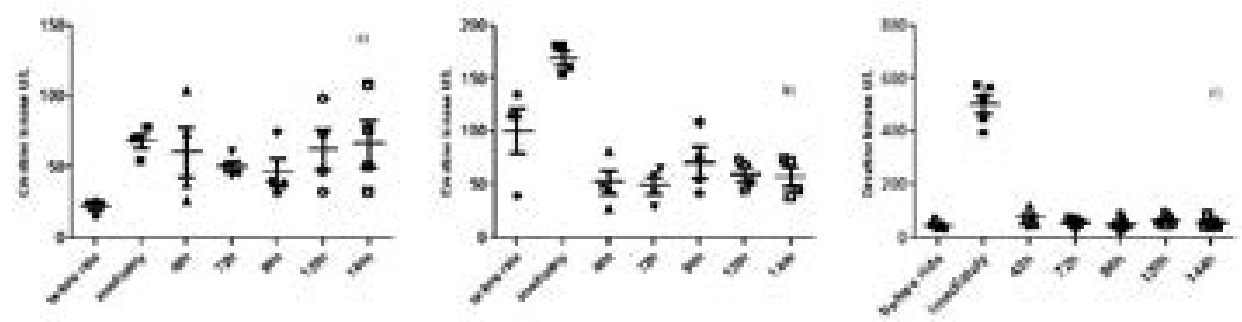

Figure 3. Creatine kinase activity (U/L) in horse serum before 40-kilometre-long endurance ride, on finishing the ride, $48 \mathrm{~h}, 72 \mathrm{~h}, 96 \mathrm{~h}, 120 \mathrm{~h}$ and $144 \mathrm{~h}$ after the ride; (a) highly adapted (b) moderately adapted (c) horses with low degree of adaptation 


\section{Concentrations of total proteins, albumins, globulins and $A / G$ ratio}

In odred to assess the influence of physical activity on the synthesis of blood proteins, in racehorses serum concentrations of total proteins, albumins and globulins, as well as the $A / G$ ratio was determined (Table 4).

Table 4. Concentrations of total proteins, albumins, globulins (g/L) and $A / G$ ratio in serum of horses which ran 2400-meter-long gallop ride and 40-kilometer-long endurance ride

\begin{tabular}{|c|c|c|c|c|}
\hline \multirow{2}{*}{ Sampling time } & \multicolumn{3}{|c|}{$\bar{X} \pm \mathrm{SD}(\mathrm{g} / \mathrm{L})$} & $\begin{array}{c}\text { A/G } \\
\text { Ratio }\end{array}$ \\
\cline { 2 - 5 } & Total proteins & Albumins & Globulins & \\
\hline \multicolumn{5}{|c|}{ Gallop race } \\
\hline before race & $71.75 \pm 10.93$ & $44.48 \pm 5.80$ & $27.27 \pm 11.73$ & 1.63 \\
\hline $72 \mathrm{~h}$ after the race & $72.65 \pm 9.64$ & $45.42 \pm 5.85$ & $27.23 \pm 11.67$ & 1.67 \\
\hline 96 $\mathrm{h}$ after the race & $71.77 \pm 12.42$ & $47.04 \pm 4.50$ & $24.73 \pm 13.52$ & 1.90 \\
\hline \multicolumn{6}{|c|}{ Endurance ride } \\
\hline before ride & $79.01 \pm 9.14$ & $44.17 \pm 5.19$ & $34.84 \pm 8.69$ & 1.27 \\
\hline immediately after the ride & $83.52 \pm 9.30$ & $46.50 \pm 3.76$ & $37.02 \pm 11.02$ & 1.26 \\
\hline 48 $\mathrm{h}$ after the ride & $76.56 \pm 9.93$ & $45.43 \pm 4.91$ & $31.13 \pm 8.05$ & 1.46 \\
\hline $72 \mathrm{~h}$ after the ride & $74.39 \pm 6.70$ & $43.85 \pm 4.84$ & $30.54 \pm 8.67$ & 1.43 \\
\hline 96 $\mathrm{h}$ after the ride & $74.50 \pm 10.11$ & $41.75 \pm 3.08^{\# \#,+}$ & $32.75 \pm 9.79$ & 1.27 \\
\hline $120 \mathrm{~h}$ after the ride & $73.45 \pm 8.04$ & $43.82 \pm 3.69$ & $29.63 \pm 8.20$ & 1.48 \\
\hline 144 $\mathrm{h}$ after the ride & $75.62 \pm 7.15$ & $43.25 \pm 4.30$ & $32.37 \pm 8.71$ & 1.34 \\
\hline
\end{tabular}

Data: means \pm SD

\# $p<0.01$ The levels of statistical significance immediately after the ride and $48 \mathrm{~h}$ to $144 \mathrm{~h}$ after the ride ${ }^{+} p<0.05$ statistically significant difference between $48 \mathrm{~h}$ to $144 \mathrm{~h}$ after the ride

It was observed that the concentration of total serum proteins in each group of horses was similar at all test times ( $p>0.05)$. In addition, the mean values of total proteins in the serum of the horses participating in both activities did not differ significantly $(p=0.0840)$, neither did the protein content regardless of the level of physical activity and the time interval after the race $(p>0.05)$. The concentration of total protein in galloping horses positively correlated with total LDH activity before $(r=0.7037, p<0.05)$, and $72 \mathrm{~h}(r=0.6096, p<0.05)$ and $96 \mathrm{~h}(r=0.8205, p<0.01)$ after the race, whilst in the participants of the endurance ride correlates with albumin concentration $48 \mathrm{~h}$ after the ride $(r=0.5927, p<0.05)$.

The results revealed no significant difference in the content of albumins $72 \mathrm{~h}$ and $96 \mathrm{~h}$ after the gallop race, in comparison to the concentration before the race $(p>0.05)$. By contrast, the endurance ride led to statistically significant differences in albumin concentrations $96 \mathrm{~h}$ after the race in comparison with the values both on completion $(p<0.01)$, and $48 \mathrm{~h}$ after the ride $(p<0.05)$. The mean values of serum albumin concentration in both groups of horses before the race did not differ significantly $(p=0.884)$. However, the difference was significant $96 \mathrm{~h}$ after the completion of activities $(p<0.01)$. 


\section{DISCUSSION}

Oxidative stress resulting from physical exercise is responsible for increasing levels of certain enzymes in skeletal muscles. Particularly interesting is the increase in LDH levels, caused by the increased production of hydroxyl radicals, which do damage muscle cells and hepatocytes (Kayatekin et al., 2002; Águila et al., 2005). Since LDH is located in the cytoplasm, if the cells damaged it easily passes into the extracellular space, resulting in increased activity in the blood plasma. After prolonged physical exercise the MDA content increases in the blood, which reflects the activity of the corresponding LDH isoenzymes and suggests possible damage of the tissues other than muscles (Chiaradia et al., 1998). Given that, in our studies (unpublished results) an increased lipid peroxidation, which accompanies the overproduction of ROS and may lead to myopathy and hemolysis induced by physical exercise, was proven, LDH was assessed in horses. It was shown that there was no change in the total activity of LDH after the gallop race, but a slight increase was observed $96 \mathrm{~h}$ on its completion in comparison to the basic level ( $p>0.05)$. A significant increase in the total activity of LDH was proven immediately after the endurance ride $(p<0.01)$, which tends to return to basic values afterwards. The difference between the activities of total LDH in horses after physical exercise of various intensity was significant both $72 \mathrm{~h}(\mathrm{p}<0.05)$ and $96 \mathrm{~h}$ after the races $(\mathrm{p}<0.01)$.

$\mathrm{LDH}$ can be found in the cells of various tissues, the measurement of its total activity has little diagnostic value; thus, it is important to define its isoenzyme forms, having in mind their distribution in certain tissues and organs. Our results showed a significant increase in the activity of LDH1: $28.39 \% 72 \mathrm{~h}$ after the gallop race $(p<0.05)$. The increasing trend remained after $96 \mathrm{~h}$, when it was $17.58 \%$ higher than the basic value $(p>0.05)$. However, the activity of other isoenzyme forms (LDH2 - LDH5) did not differ significantly $(p>0.05)$. The revealed isoenzyme distribution indicates higher levels of LDH originating from the myocardium. This finding is in accordance with the data that in horses after physical activity besides enzymes from muscles, there were some LDH isoenzyme forms originating from other tissues (Chiaradia i sar., 1998).

After the completion of the 40-kilometer-long endurance ride a tendency of rise in the LDH1 activity at all sampling times was noticed in comparison to the values before and on crossing the finishing line $(p<0.01)$. This activity was $19.40 \%$ higher $72 \mathrm{~h}$ and $25.93 \%$ higher than the basic level $96 \mathrm{~h}$ after the ride. The kinetics of the LDH2 activity was similar to that of LDH1, significantly increasing at all time intervals in comparison to the values which preceded the ride and were measured immediately after it $(p<0.05$ to $p<0.001)$. However, a significant rise was present in the activity of LDH4, the marker of skeletal muscle damage, all the time after the race $(p<0.01)$. LDH5, which points to the degree of liver damage, significantly rose only immediately after the endurance ride $(p<0.01)$, declining at all other time intervals in comparison to the basic level $(p<0.05$ to $p<0.001)$, which indicates that there was a quick adaptation of hepatocytes to the increased needs resulting from prolonged physical exercise. 
The available data on the activities of $\mathrm{LDH}$ and its isoforms in horses are limited, and are difficult to compare. Our results are in agreement with the findings of Balogh et al. (2001), who demonstrated a significant increase in LDH activity $(p<0.05)$ immediately after exercise in horses which participated in prolonged physical exercise (Pentathlon). After a 24-hour rest LDH activity returned to the approximate value prior to the race. This type of testing was performed more frequently on people. Thus, Watson et al. (2005) confirmed that oxidative stress developed in athletes due to physical exercise does not lead to changes in the functionality of the liver, but increases the level of TBARS in skeletal muscles. This may cause the rise in the concentrations of $\mathrm{LDH}$ and it in turn can increase the production of hydroxyl radicals, which cause muscle damage. However, tests of serum LDH activity in the maximum and submaximum cycloergometric test performed on amateur athletes and cyclists by Tauler et al. (2004) indicate that both tests do not lead to increased LDH activity, which is in contradiction with our results.

Analysis of LDH isoenzyme forms revealed that due to long low intensity physical exercise and development of oxidative stress, in the 40-kilometer endurance ride, damage to the myocardium, skeletal muscles and hepatocytes occurs, in contrast to the 2400-meter gallop race, which causes changes only in the myocardium. These may correlate with the duration and intensity of exercise.

The activity of CK showed various degrees (high, medium and low) of adaptation of horses to exercise, with consequently different levels of its activity immediately after the race and the speed and dynamics of returning to basic levels, depending on the the degree of oxidative stress.

Stenuous and/or long-lasting exercise creates stress to the body and therefore raises the activity of the adrenal cortex, resulting in at least 2-3 fold increased cortisol levels (Freestone et al., 1991; Lassourd et al., 1996; Nogueira and Barnabas, 1997; Horohov et al., 1999). It is physiologically justified because this hormone has a strong influence on metabolism, increases glycogenolysis and gluconeogenesis, promotes the mobilization of fat, stimulates the synthesis of proteins needed for damage repair, stimulates the transformation of noradrenaline into adrenaline, increases the sensitivity of adrenaline receptors etc. Except for these metabolic effects, cortisol induces the increase of blood concentrations of some cytokines, in particular, a significant increase in IL6, IL8, IL10 and TNF. At the same time, the very damaged muscle and other tissues during intense and/or long-term excercise trigger the secretion of cytokines (Pyne, 1994; Fallon and Sivyer, 1999; Fallon, 2001). There are many explanations for their increased production. They primarily stimulate the activity of the immune system, which is necessary in increased physical activity due to intensive contact with foreign agents which could lead to negative consequences for the organism. In addition, these cytokines, particularly IL6, are powerful stimulators of synthesis of acute phase proteins and their release into the blood (Pyne, 1994; Fallon, 2001).

Total protein concentrations did not change significantly in the tested time intervals in the horses completing the gallop race or endurance ride. Specifically, $72 \mathrm{~h}$ and $96 \mathrm{~h}$ after galloping their concentration slightly increased, as well as 
immediately after the endurance ride $(p>0.05)$, whilst in all tested intervals after the ride it was slightly lower than before the race $(p>0.05)$. These results suggest that, regardless of the different intensity and duration of exercise, both races did not lead to significant changes in protein concentrations. This finding is quite expected, given that in racing animals changes in proteins are mainly due to haemoconcentration (Rose et al., 1977; Rose and Hadgson, 1982; Poso, 1983; Jablonska et al., 1991; Stevanovic et al., 1996; White et al., 2001; Manohar et al., 2004; de Miranda et al., 2009) and that water was available to horses ad libitum. Galloping horses consumed water after the race and the participants of the endurance ride drank during break and veterinary supervision. During endurance weather conditions (high humidity and low temperature) contributed to the absence of haemoconcentration. These results are in agreement with the findings of Nostell et al. (2006) who, comparing the physiological response of the standardized exercise test on a treadmill used to simulate the race on the track in thoroughbred racing trotters, also failed to observe differences in total plasma protein concentration after exercise and during recovery. However, our findings disagree with those presented by Balogh et al. (2001), who in horses jumping over hurdles and participating in pentathlon, on finishing the activities and $24 \mathrm{~h}$ later found a significant increase in total protein concentration. These differences in protein concentration can be due to different degrees and intensity of exercise and, consequently, different energy requirements for different types of physical activity, as well as a variety of environmental conditions.

Although the total protein content did not change significantly, we assessed the concentration of the major protein fractions, i.e. serum albumins, because these belong to the so-called negative acute-phase proteins and their concentration points to the possible development of disproteinaemia. Both 72 and $96 \mathrm{~h}$ after highintensity physical activity (2400-meter gallop race) a significant difference in the concentration of albumin was detected in comparison with the values before the race $(p>0.05)$. However, $96 \mathrm{~h}$ after the long-standing low-intensity physical activity (40-kilometer endurance ride) there was a statistically significant decrease in serum albumin concentration in comparison to the value immediately after the race and 48 $h$ later $(p<0.01$ and $p<0.05)$. The concentration of albumin in both groups of racing horses before the race was roughly the same. Comparing the values after the activities, it was found that $96 \mathrm{~h}$ after the endurance ride the content of albumin was significantly lower than at the same time after the gallop race $(p<0.01)$. However, the decline in serum albumin after endurance is in agreement with literature data obtained in humans, which show that the concentration of albumin in athletes decreased after exercise (Fallon and Sivyer, 1999) and ultramarathons (Fallon, 2001). In the acute phase albumin concentration decreases by $10-50 \%$ (Toussaint, 2005). However, this may not be due to a real decline in serum albumin due to the development of acute phase, but is often a reflection of increased synthesis of other acute-phase proteins which are all plasma globulins (Pritchard et al., 2009).

Regarding LDH, its total activity in the serum after the gallop race was not significantly altered, but the determination of isozyme distribution demonstrated a 
significant increase in activity LDH1 $72 \mathrm{~h}$ after the race $(\mathrm{p}<0.05)$, indicating that this type of exercise leads to cell damage in the myocardium. Total LDH activity in horses participating in the endurance ride significantly increased on finishing the activity $(p<0.01)$. Significant increase in LDH1 $144 \mathrm{~h}$ after the endurance ride and LDH2 at all observed intervals $(p<0.05)$ refers to the damage of myocardium cells. Significant increase in LDH4 in all tested intervals after endurance ride $(p<0.01)$ points to skeletal muscle cell damage, whilst the increased LDH5activity immediately after the race $(p<0.01)$ indicates hepatocyte damage caused by this type of exercise.

The activity of $\mathrm{CK}$ pointed to high, moderate and low degree of adaptability of the horses to exercise. The 2400-meter gallop race and the 40-kilometer endurance ride did not influence tha concentration of total proteins and globulins. Dysproteinaemia was proven, precisely hypoalbuminemia $96 \mathrm{~h}$ after the endurance ride, in comparison to the value on crossing the finishing line $(p<0.01)$ and $48 \mathrm{~h}$ later $(p<0.05)$.

\section{ACKNOWLEDGEMENTS:}

This study was supported by the Ministry of Education, Science and Technological development of the Republic of Serbia (Project No. 173034; 31085)

Adress for correspondence:

Slavoljub Jović, MSc, PhD

Department of Physiology,

Faculty of Veterinary Medicine, University of Belgrade,

Bulevar oslobođenja 18,

11000 Belgrade, Serbia

E-mail: romanov@vet.bg.ac.rs

\section{REFERENCES}

1. Abeni F, Dal Prà A, Bertin G, Calamari L, 2013, Serum protein fraction in mature horses and relationship with metabolic and hematological parameters, J Equine Vet Sci, 1-7,

2. Adamu L, Noraniza MA, Rasedee A, Bashir A, 2012, Effect of age and performance on physical, hematological, and biochemical parameters in endurance horses, J Equine Vet Sci, 1-6,

3. Aguilo A, Tauler P, Fuentespina E, Tur J, Cordova A, Pons A, 2005, Antioxidant response to oxidative stress induced by exhaustive exercise, Physiol Behav, 84, 1-7.

4. Anderson MG, 1975, The influence of exercise on serum enzyme levels in the horse, Equine Vet $J$, 7, 160-5.

5. Arai T, Hosoya M, Nakamura M, Magoori E, Uematsu Y, Sako T, 2002, Cytosolic ratio of malate dehydrogenase/lactate dehydrogenase activity in peripheral leukocytes of race horses with training, Res Vet Sci, 72, 241-4.

6. Arai T, Inoue A, Uematsu Y, Sako T, Kimura N, 2003, Activities of enzymes in the malate-aspartate shuttle and the isoenzyme pattern of lactate dehydrogenase in plasma and peripheral leukocytes of lactating Holstein cows and riding horses, Res Vet Sci, 75, 15-9.

7. Balogh N, Gaál T, Ribiczeyné PS, Petri A, 2001, Biochemical and antioxidant changes in plasma and erythrocytes of pentathlon horses before and after exercise, Vet Clin Path, 30,4, 214-8.

8. Boffi FM, Cittar J, Balskus G, Muriel M, Desmaras E, 2002, Training-induced apoptosis in skeletal muscle, Equine Vet J, 34, 275-8.

9. Cheung K, Hume P, Maxwell L, 2003, Delayed onset muscle soreness: treatment strategies and performance factors, Sports Med, 33, 145-64.

10. Chevion S, Moran DS, Heled Y, Shani Y, Regev G, Abbou B et al, 2003, Plasma antioxidant status and cell injury after severe physical exercise, Contributed by Earl R Stadtman February 24. 
11. Chiaradia E, Avellini L, Rueca F, Spaterna A, Porciello F, Antonioni MT, et al, 1998, Physical exercise, oxidative stress and muscle damage in racehorses, Comp Biochem Phys B, 119,4, 833-6.

12. Close GL, Ashton T, McArdle A, MacLaren DPM, 2005, The emerging role of free radicals in delayed onset muscle soreness and contraction-induced muscle injury, Comp Biochem Phys A, 142, 257-66.

13. Davies KJA, Quintanilha AT, Brooks GA, Packer L, 1982, Free radicals and tissue damage produced by exercise, Biochem Bioph Res Co, 107, 4, 1198-205.

14. de Miranda RL, Mundim AV, Saquy ACS, Costa AS, Guimaraes EC, Goncalves FC, et al, 2009, Biochemical serum profile of equines subjected to team penning, Comp Clin Pathol, 18, 313-9.

15. Fallon KE, 2001, The acute phase response and exercise: the ultramarathon as prototype exercise, Clin J Sport Med, 11, 1, 38-43.

16. Fallon KE, Sivyer K, 1999, Changes in haematological parameters and iron metabolism associated with a 1600 kilometre ultramarathon, Brit J Sport Med, 33, 27-32.

17. Freestone JF, Wolfsheimer KJ, Kamerling SG, Church G, Hamra J, Bagwell C, 1991, Exercise induced hormonal and metabolic changes in Thoroughbred horses: effects of conditioning and acepromazine, Equine Vet J, 23, 219-23.

18. Gondim FJ, Zoppi CC, dos Reis Silveira L, Pereira da Silva L, Vaz de Macedo D, 2009, Possible relationship between performance and oxidative stress in endurance horses, J Equine Vet Sci, $29,4$.

19. Gutteridge JM, Halliwell B, 1990, Reoxygenation injury and antioxidant protection: a tale of two paradoxes, Arch Biochem Biophys, 283, 2, 223-6.

20. Halliwell $B, 1991$, Reactive oxygen species in living systems: source, biochemistry, and role in human disease, Am J Med, 91, 14-22.

21. Hargreaves BJ, Kronfeld DS, Waldron JN, Lopes MA, Gay LS, Saker KE et al., 2002, Antioxidant status and muscle cell leakage during endurance exercise, Equine Vet J, 116-21.

22. Horohov DW, Dimock AN, Guirnalda PD, Folsom RW, McKeever KH, Malinowski K, 1999, Effect of exercise on the immune response of young and old horses, Am J Vet Res, 60, 643-7.

23. Jablonska EM, Ziolkowska SM, Gill J, Szykula R, Faff J, 1991, Changes in some haematological and metabolic indices in young horses during the first year of jump-training, Equine Vet $J$, 23, 4, 309-11.

24. Kayatekin BM, Gönenç S, Açikgöz O, Uysal N, Dayi A, 2002, Effects of sprint exercise on oxidative stress in skeletal muscle and liver, Eur J Appl Physiol, 87, 2, 141-4.

25. Kirschvink $N$, de Moffarts $B$, Farnir F, Pincemail J, Lekeux $P, 2006$, Investigation of blood oxidant/antioxidant markers in healthy competition horses of different breeds, Equine Vet J, 36, 239-44.

26. Lassourd V, Gavrard V, Laroute V, Alvineire M, Bernard P, Courtot D, et al., 1996, Cortisol disposition and production rate in horses during rest and exercise, Am J Physiol, 271, 25-33.

27. LawanA, Noraniza MA, Rasedee A, BashirA, 2010, Effects of race distanceon physical, hematological and biochemical parameters of endurance horses, Am J Anim Vet Sci, 5, 244-8.

28. Li G, Lee P, Mori N, Yamamoto I, Arai T, 2012, Long term intensive exercise training leads to a higher plasma malate/lactate dehydrogenase $(\mathrm{M} / \mathrm{L})$ ratio and increased level of lipid mobilization in horses, Vet Res Commun, 36, 149-55.

29. Manohar M, Goetz TE, Hassan AS, 2004, $\mathrm{NaHCO}_{3}$ does not affect arterial $\mathrm{O}_{2}$ tension but attenuates desaturation of hemoglobin in maximally exercising Thoroughbreds, JAppl Physiol, 96, 134956.

30. Margaritis I, Palazzetti S, Rousseau AS, Richard MJ, Favier A, 2003, Antioxidant supplementation and tapering exercise improve exercise-induced antioxidant response, J Am Coll Nutr, 22, 2, 147-56.

31. Marlin DJ, Fenn K, Smith N, Deaton CD, Roberts CA, Harris PA et al., 2002, Changes in circulatory antioxidant status in horses during prolonged exercise, J Nutr, 132, 1622 S-7S.

32. Marlin DJ, Fenn K, Smith N, Deaton CD, Roberts CA, Harris PA et al., 2002, Changes in circulatory antioxidant status in horses during prolonged exercise, J Nutr, 132, 1622 S-7S.

33. McBride J, Kraemer WJ, 1999, Free radicals, exercise and antioxidants, J Strength Cond Res, 13, 175-83.

34. Morillas-Ruiz JM, Villegas García JA, López FJ, Vidal-Guevara ML, Zafrilla P, 2006, Effects of polyphenolic antioxidants on exercise - induced oxidative stress, Clin Nutr, 25, 3, 444-53. 
35. Nogueira GP, Barnabe RC, 1997, Is the Thoroughbred race-horse under chronic stress?, Braz J Med Biol Res, 30, 1237-9.

36. Nostell K, Funkquist P, Nyman G, Essén-Gustavsson B, Connysson M, Muhonen S et al., 2006, The physiological responses to simulated race tests on a track and on a treadmill in Standardbred trotters, Equine Vet J, 36, 123-7.

37. Piccione G, Giannetto C, Fazio F, Casella S, Caola G, 2009, A comparison of daily rhythm of creatinine and creatine kinase in the sedentary and athlete horse, J Equine Vet Sci, 29, 7, 575-80.

38. Poso AR, Soveri T, Oksanen HE, 1983, The effect of exercise on blood parameters in Standardbred and Finnish-bred horses, Acta Vet Scand, 24, 2, 170-84.

39. Powers SK, Lenon SL, 1999, Analysis of cellular responses to free radicals: focus on exercise and skeletal muscle, $P$ Nutr Soc, 58, 4, 1025-33.

40. Pritchard JC, Burn CC, Barr ARS, Whay HR, 2009, Haematological and serum biochemical reference values for apparently healthy working horses in Pakistan, Res Vet Sci, 87, 389-95.

41. Pyne DB, 1994, Exercise - induced muscle demage and inflamation: a review, Aust J Sci Med Sport, 26, 3-4, 49-58.

42. Ramzan PHL, Palmer L, 2010, Musculoskeletal injuries in Thoroughbred racehorses: A study of three large training yards in Newmarket, UK (2005-2007), Vet J, 187, 3, 325-9.

43. Reid MB, Haack KE, Franchek KM, Valberg PA, Kobzik L, West MS, 1992, Reactive oxygen in skeletal muscle, I. Intracellular oxidant kinetics and fatigue in vitro, J Appl Physiol, 73, 1797-804.

44. Rose R, Hadgson DR, 1982, Haematological and plasma biochemical paramaters in endurance horses during training, Equine Vet $J, 14,144-8$.

45. Rose R, Purdue RA, Hansley W, 1977, Plasma biochemistry alternations in horses during one endurance ride, Equine Vet $J, 9,3,122-6$.

46. Sen CK, 1995, Oxidants and antioxidants in exercise, J Appl Physiol, 79, 3, 675-86.

47. Sjodin B, Hellsten Westing YH, Apple FS, 1990, Biochemical mechanisms for oxygen free radical formation during exercise, Sports Med, 10, 236-54.

48. Slater TF, 1987, Free radicals and tissue injury: fact and fiction, Brit J Cancer Suppl, 8, 5-10.

49. Soares JCM, Zanella R, Bondan C, Alves LP, de Lima MR, Adriana Costa da Motta, et al., 2011, Biochemical and antioxidant changes in plasma, serum, and erythrocytes of horses before and after a Jumping Competition, J Equine Vet Sci, 31, 357-60.

50. Stevanović Jelka, Vitić Jelena, Tarilović Ružica, Trailović D, 1994, Effects of the 1600m long distance race on proteins, lipoproteins and lipids in Standardbred horses, Acta Vet, 44, 2-3, 57-62.

51. Stevanović Jelka, Vitić Jelena, Trailović Ružica, Trailović D, 1996, Some protein, lipoprotein and lipid alterations in serum of show jumping horses during different phases of training, Acta Vet, (Belgrade) 46, 2-3, 81-6.

52. Tauler P, Aguiló A, Gimeno I, Guix P, Tur JA, Pons A, 2004, Different effects of exercise tests on the antioxidant enzyme activities in lymphocytes and neutrophils, $J$ Nutr Biochem, 15, 8, 479-84.

53. Tauler P, Sureda A, Cases N, Aguiló A, Rodríguez-Marroyo JA, Villa G, et al., 2006, Increased lymphocyte antioxidant defences in response to exhaustive exercise do not prevent oxidative damage, J Nutr Biochem, 17, 10, 665-71.

54. Toussaint MJM, 2005, Acute phase protein in different species measured as a tool to assess animal health, European Collowuium Report.

55. Votion DM, Fraipont A, Goachet AG, Robert C, van Erck E, Amory H, et al., 2010, Alterations in mitochondrial respiratory function in response to endurance training and endurance racing, Equine Vet J, 42, 38, 268-74.

56. Watson TA, Callister R, Taylor RD, Sibbritt DW, MacDonald-Wicks LK, Garg ML, 2005, Antioxidant restriction and oxidative stress in short - duration exhaustive exercise, Med Sci Sports Exer, $37,1,63-71$.

57. Watson TA, MacDonald-Wicks LK, Garg ML, 2005, Oxidative stress and antioxidants in athletes undertaking regular exercise training, Int $J$ Sport Nutr Exe, 15, 2, 131-46.

58. White A, Estrada M, Walker K, Wisnia P, Filgueira G, Valdes F et al., 2001, Role of exercise and ascorbate on plasma antioxidant capacity in Throughbred race horses, Comp Biochem Phys, 128, 99-104.

59. Williams CA, Kronfeld DS, Hess TM, Saker KE, Waldron JN, Crandell KM, et al., 2004, Antioxidant supplementation and subsequent oxidative stress of horses during an $80-\mathrm{km}$ endurance race, J Anim Sci, 82, 588-94. 


\title{
UTICAJ INTENZITETA OPTEREĆENJA TRKAČKIH KONJA NA AKTIVNOST LAKTAT DEHIDROGENAZE, KREATIN KINAZE I SINTEZU PROTEINA
}

\author{
JOVIĆ S, STEVANOVIĆ JELKA, BOROZAN SUNČICA, DIMITRIJEVIĆ B \\ i MILOSAVLJEVIĆ P
}

\section{SADRŽAJ}

Cilj rada je bio utvrđivanje efekata fizičkog opterećenja različitog intenziteta na stepen oštećenja ćelija pojedinih organa usled pojačane produkcije slobodnih radikala, kao i adaptiranosti organizma na fizičko opterećenje.

$U$ ispitivanju su učestvovali zdravi punokrvni trkački konji, starosti 3-5 godina, podeljeni u dve grupe. Prva grupa je podvrgnuta kratkotrajnom fizičkom opterećenju visokog intenziteta tokom galopske trke na $2400 \mathrm{~m}$, a ispitivani parametri su određivani pre trke, $48 \mathrm{~h}$ i $72 \mathrm{~h}$ posle trke. Druga grupa je bila podvrgnuta prolongiranom fizičkom opterećenju niskog intenziteta tokom endjurans trke na $40 \mathrm{~km}$, a ispitivani parametri su određivani pre trke, neposredno nakon trke, 48 h, 72 h, 96 h, 120 h i 144 h posle trke.

Ukupna aktivnost LDH se menjala 72 h i 96 h nakon galopske trke $(p>0,05)$, dok najveću aktivnost dostiže neposredno nakon endjurans trke. Elektroforetskim razdvajanjem LDH kod svih ispitivanih konja ustanovljeno je 5 izoformi. Aktivnost LDH1 $72 \mathrm{~h}$ nakon galopske trke se značajno povećala u odnosu na aktivnost pre trke $(p<0,05)$, dok se aktivnost ostalih izoenzimskih oblika, LDH2-LDH5, nije statistički značajno razlikovala $(p>0.05)$. Nakon endjuransa uočen je porast aktivnosti LDH1 u svim ispitivanim vremenskim intervalima, sa maksimalnom aktivnošću 96 h i 144 h u odnosu na period pre i neposredno posle trke $(p<0.01)$. Porast aktivnosti LDH2 je bio statistički značajno veći 48 h, 72 h, 96 h i 120 h $(p<0,05)$ u poređenju sa vrednostima pre trke i $48 \mathrm{~h}, 72 \mathrm{~h}, 96 \mathrm{~h}, 120 \mathrm{~h}$ i 144 $\mathrm{h}(\mathrm{p}<0,05) \mathrm{u}$ odnosu na vrednost neposredno posle trke. Aktivnosti izoforme LDH3 ispoljava statistički značajan pad, a LDH5 povećanje neposredno nakon endjuransa $(p<0,01)$, dok LDH4 značajno raste $u$ svim ispitivanim vremenskim intervalima posle endjuransa $(p<0,01)$. Aktivnost $C K$ je imala visoki, srednji i nizak stepen adaptiranosti konja na opterećenje.

Koncentracija ukupnih proteina, albumina i globulina se u svim analiziranim intervalima kretala u fiziološkim granicama, izuzev endjuransa kada je ustanovljen statistički značajan pad koncentracije albumina 96 h nakon trke $(p<0,01)$.

Prolongirano fizičko opterećenje niskog intenziteta dovodi do oštećenja ćelija miokarda, mišićnog tkiva, hepatocita i hipoalbuminemije kao posledice stvaranja slobodnih radikala. 